\section{Characteristics of male and female injecting drug users of the AjUDE-Brasil II Project}

\author{
Características de homens e mulheres usuários \\ de drogas injetáveis do Projeto AjUDE-Brasil II
}

Ana Maria de Oliveira Cintra 1,2 Waleska Teixeira Caiaffa ${ }^{2}$ Sueli Aparecida Mingoti 3 Projeto AjUDE-Brasil II 4

\footnotetext{
1 Departamento de Psicologia, Universidade Federal de São João Del-Rei, São João Del-Rei, Brasil.

2 Faculdade de Medicina Universidade Federal de Minas Gerais,

Belo Horizonte, Brasil. 3 Instituto de Ciências Exatas, Universidade Federal de Minas Gerais, Belo Horizonte, Brasil. 4 Other members listed at the end of the paper.

Correspondence W. T. Caiaffa Departamento de medicina Preventiva, Faculdade de Medicina, Universidade Federal de Minas Gerais. Av. Alfredo Balena 190 Belo Horizonte, $M G$ 30130-100, Brasil. wcaiaffa@medicina.ufmg.br
}

\section{Abstract}

The object of this study is to compare female and male injection drug users (IDUs) in terms of sociodemographic profile and aspects of their initiation to the use of injection drugs. It was a cross-sectional and multicentric study realized in 2000-2001 in six Brazilian syringe-exchange programs. 146 women and 709 men were interviewed, with average ages of 29.5 and 28.3 years, respectively. Both began injection drug use at similar ages, 18.6 and 19.3, for women and men, respectively, although women report more frequently than men that they were initiated by a sexual partner to acquiring drugs and syringes, and to the act of injection. Compared to men, women report significantly more regular sexual partners (83\% versus $72 \%$ ); fewer casual partners (39\% versus 58\%), more use of injection drugs with their partners, as well as more "exchange" of sex for drugs. Among HIV-seropositive individuals, women show less education, had more chance of their sexual partners participating in their initiation to injection drugs, and report sexual partners that used injection drugs more frequently. Female IDUs exhibit aspects of behavior indicating greater vulnerability to HIV infection than do males.

Intravenous Substance Abuse; HIV; Acquired Immunodeficiency Syndrome; Harm Reduction

\section{Introduction}

The trajectory of the HIV/AIDS epidemic around the world has been characterized by an increase in female exposure, both sexual and through injection drug use 1 .

In Brazil, of the 362,364 cases of AIDS documented through June, 2004, 111,314 were women and 241,050 were men. HIV transmission through heterosexual sexual relations has increased significantly in recent years, as evidenced by the progressive shift in the rate of AIDS cases between men and women 2 .

Between 1983 and 1990, injection drug users (IDUs) represented $31.6 \%$ of all the AIDS notifications among women; today, they represent $5.7 \%$. However, the percentage of AIDS cases among women for which the mode of transmission is recorded to be unknown, oscillates between $20 \%$ and $30 \%$, depending on the year, suggesting lack of knowledge of the circumstances of transmission and of their sexual partners 3 .

Risk behaviors for HIV infection have been differentiated between males and females, notably among IDUs. Various international studies demonstrate that HIV infection among female and male IDUs are associated with distinct factors, predominantly heterosexual activity and the presence of recent sexually transmitted diseases (STDs) 4, as well as syringe sharing and unprotected sexual contact with an- 
other IDUs 5 . Also in Brazil, a study 6 of 250 injection cocaine users showed greater prevalence of HIV among women, attributed to unprotected heterosexual sex with IDUs. On the other hand, among 2,994 women attended by the Anonymous Testing Service, it was found that low education, low family income, injection drug use, and clinical history of STDs are risk factors for HIV infection 7 .

Important evidence on the circumstances of initiation to injection drug use among women and on the risk of HIV seroconversion have been accumulating. The necessity for assistance with the act of injecting oneself, whether it be from sexual partners or from other women, as well as dependence in acquiring the drugs, have been associated with HIV seroconversion 8,9,10.

In addition, gender differences may be associated with different risks of HIV infection. Grimberg 11 analyzed gender differences among women living with HIV in Argentina, suggesting that women were infected through unprotected sex and syringe sharing. In Brazil, a study in Rio de Janeiro and Santos, described that, whereas among male IDUs there may be greater peer pressure to share injection materials with group members, among women there may be a tendency toward private use of injection drugs, together with the sexual partner, probably due to prejudice against the practice 12 .

Besides those aspects described above, some studies demonstrate that women who have regular sexual partners, sex workers, and those with IDUs partners or those who obtain drugs in exchange for sex, have a greater chance of being infected by HIV 10,13.

In order to contribute to a field in which comparisons between female and male IDUs in Brazil are scarce, this study proposes to characterize how women and men are introduced to injection drug use, to verify needle and syringe sharing and the use of condoms, in addition to the relationship between sex and drugs, for both men and women. The hypothesis being investigated in this study is that women are, more frequently than men, inserted in risk situations for infection by HIV, both in the context of initiation to and sharing of drugs as well as in the context of sexual activity.

\section{Methods}

The data analyzed derive from a cross-sectional and multicentric study, the AjUDE-Brasil II Project, undertaken in 2000/2001, in syringeexchange programs (SEP) in Porto Alegre and Gravataí (State of Rio Grande do Sul), São José do Rio Preto (State of São Paulo), Florianópolis and Itajaí (State of Santa Catarina) and Salvador (State of Bahia).

Eligible participants, recruited by the harm reduction project's outreachers, were 18 years of age or older and reported injection drug use during the last five years, independent of frequency and quantity. Such information was evaluated operationally through questions in the collection instrument and answered by the interviewer, in order to improve the reliability of the eligibility criteria (for example, presence of stigmas, information regarding drug preparation). Individuals that did not fulfill the criteria were not included.

Face to face interviews were performed by previously trained and monitorated technicians, using a structured interview instrument 14 . It covered sociodemographic data, drug use and sexual behaviors, and other dimensions of the individuals' lives. Other data collected were fingerprint blood samples, using filter paper, to test for HIV, hepatitis B and C, HTLV I and II, and syphilis 15 .

The power to test the hypothesis that women ( $n=146$ ) were more exposed to risk behaviors than men ( $\mathrm{n}=709)$ varied from $90.4 \%$ to $99 \%$, taking into account the smallest and the greatest proportion of exposure among men, considered as controls, in a hypothetical case-control study (5.3\% for the smallest and $66.9 \%$ for the greatest exposure, with odds ratios (OR) of 2.05 and 6.61 , respectively).

The variables analyzed, defined $a$ priori keeping in mind the aims of the study and their importance in similar studies, were initially stratified by sex. Subsequently, comparative analyses were conducted in the subgroup of HIV-seropositive women and men. Student's tTest, Pearson's Chi-square Test, or the Fisher's Exact Test were used. Unadjusted Mantel-Haenszel OR was used to measure the force of association 16,17 .

Logistic regression models were used to evaluate the independent effects of each variable that was potentially associated with the seroprevalence of HIV, controlled for confounding factors 18 . The event considered was female HIV-seropositivity, compared with male HIVseropositivity. Variables that were associated with the event with $p$-values $\leq 0.20$ in the univariate analysis were tested in the multivariate analysis, so that possible event predictors were not excluded in the analysis 18. Adjustment was made for the SEP where the individual was recruited, due to their great heterogeneity, with those variables with $p \leq 0.05$ and biological plausibility remaining in the final model. 
This protocol follows all of the ethical principles of Resolução 196/96 and was approved by the Ethics Committee of the Universidade Federal de Minas Gerais under process number 168/99, dated March 1, 1999

\section{Results}

\section{Comparison between women and men}

Of the 855 IDUs participating in this study, 17\% were women and $83 \%$ men, with a similar average age $(29.5 \pm 8.58$ years for women and $28.3 \pm$
8.16 years for men). A significant difference was observed in education: $57 \%$ of men and $45 \%$ of women reported having completed the 5 th to 8 th grade $(\mathrm{p}=0.055)$

The distribution of men and women by the SEP city did not exhibit homogeneity; nor did marital status, skin color, and occupation. The greater proportion of women were married or widowed, not white, and did not have an occupation during the six months prior to the interview (Table 1).

With regard to injection drug use, the average ages of initiation, whether they be with injection or non-injection drugs, were not signif-

Table 1

Sociodemographic profile of female and male injection drug users (IDUs). AjUDE-Brasil II Project, 2000/2001.

\begin{tabular}{|c|c|c|c|c|c|}
\hline \multirow[t]{2}{*}{ Characteristics $^{\star}$} & \multicolumn{2}{|c|}{ Females $(n=146)$} & \multicolumn{2}{|c|}{ Males $(n=709)$} & \multirow[t]{2}{*}{$p^{\star \star}$} \\
\hline & $n$ & $\%$ & $n$ & $\%$ & \\
\hline Age bracket (years) & & & & & 0.478 \\
\hline$<20$ & 17 & 12 & 82 & 11 & \\
\hline $20-30$ & 71 & 49 & 389 & 55 & \\
\hline $31-40$ & 38 & 26 & 170 & 24 & \\
\hline$>41$ & 19 & 13 & 68 & 10 & \\
\hline Education & & & & & 0.055 \\
\hline No education & 5 & 4 & 24 & 3 & \\
\hline 1st_-4th Primary & 56 & 40 & 196 & 29 & \\
\hline $5^{\text {th- }} 8^{\text {th }}$ Primary & 63 & 45 & 383 & 57 & \\
\hline Secondary school or higher & 16 & 11 & 68 & 11 & \\
\hline Syringe-exchange program city & & & & & $<0.01$ \\
\hline Porto Alegre & 49 & 34 & 206 & 29 & \\
\hline São José do Rio Preto & 42 & 29 & 86 & 12 & \\
\hline Itajaí & 12 & 8 & 85 & 12 & \\
\hline Florianópolis & 9 & 6 & 48 & 7 & \\
\hline Salvador & 27 & 18 & 176 & 25 & \\
\hline Gravataí & 7 & 5 & 108 & 15 & \\
\hline Marital status & & & & & $<0.001$ \\
\hline Single & 61 & 42 & 406 & 57 & \\
\hline Married or co-residing & 70 & 48 & 218 & 31 & \\
\hline Separated & 7 & 5 & 69 & 10 & \\
\hline Widowed & 8 & 5 & 14 & 2 & \\
\hline Skin color & & & & & 0.011 \\
\hline White & 54 & 37 & 346 & 49 & \\
\hline Non-white & 91 & 63 & 362 & 51 & \\
\hline Occupation & & & & & 0.030 \\
\hline No & 50 & 36 & 179 & 26 & \\
\hline Yes & 91 & 64 & 498 & 74 & \\
\hline
\end{tabular}

* Data without information were excluded $(n=2)$;

** Comparison of proportion (Pearson's $\chi^{2}$ ). 
icantly different. Nor were the average amount of time using injection drugs $(10.1 \pm 7.8$ years for women and $9.6 \pm 7.8$ years for men). Also not showing significative difference between the sexes were the proportion of beginners, defined here as those IDUs with up to three years of injection drug use, or the frequency of injection drug use in the last six months: $23 \%$ of women and $17 \%$ of men reported using two to four times per week in the last six months.

As for their introduction to injecting drugs (Table 2), women, as compared to men, had a greater chance of getting the drug for the first injection from a sexual partner $(\mathrm{OR}=21.6$; 95\%CI: 8.2-52.5), from intimate friends (OR = 2.8; 95\%CI: 1.4-5.5), and acquaintances (OR = 3.0; 95\%CI: 1.5-6.2), as compared to obtaining drugs on their own or through other means. Regarding injection equipment used for the first time, such as needles and syringes, $55 \%$ of men and $43 \%$ of women obtained them in pharmacies. A greater proportion of women (compared to men) reported to have their materials through sexual partners as obtaining them in pharmacies $(\mathrm{OR}=10.8$; 95\%CI: 4.625.6). As regards obtaining injection materials from intimate friends, acquaintances, drug dealers, and other people, significant differences between men and women were not observed.

A larger proportion of women were helped in their first injection by a sexual partner, having 12 times greater chance of being helped by a sexual partner than injecting by oneself without help (OR $=12.6$; 95\%CI: 5.7-28.4). As for the other categories, including intimate friends and acquaintances, significant associations were not observed.

As for sharing, defined here as "to give, loan, or receive needles and syringes", significant differences according to sex were not documented. Regarding giving or loaning used syringes and/or needles, $52 \%$ of women and men had

Profile of initiation to drug use among female and male injection drug users (IDUs). AjUDE-Brasil II Project, $2000 / 2001$.

\begin{tabular}{|c|c|c|c|c|c|c|}
\hline \multirow[t]{2}{*}{ Characteristics* } & \multicolumn{2}{|c|}{ Females } & \multicolumn{2}{|c|}{ Males } & \multirow[t]{2}{*}{ OR } & \multirow[t]{2}{*}{$95 \% \mathrm{Cl}^{\star x}$} \\
\hline & $\mathrm{n}$ & $\%$ & $\mathrm{n}$ & $\%$ & & \\
\hline \multicolumn{7}{|l|}{ Obtaining drugs } \\
\hline By oneself or other means $s^{\star \star \star}$ & 14 & 10 & 173 & 24 & 1.0 & \\
\hline Sexual partner & 25 & 17 & 15 & 2 & 21.6 & $8.3-52.5$ \\
\hline Intimate friend & 45 & 31 & 201 & 28 & 2.8 & $1.4-5.5$ \\
\hline Acquaintance & 30 & 21 & 124 & 17 & 3.0 & $1.5-6.2$ \\
\hline Drug dealer & 31 & 21 & 195 & 27 & 2.0 & $1.0-4.0$ \\
\hline \multicolumn{7}{|l|}{ Obtaining materials } \\
\hline Pharmacy & 62 & 43 & 388 & 55 & 1.0 & \\
\hline Sexual partner & 19 & 13 & 11 & 2 & 10.8 & 4.6-23.6 \\
\hline Relative & 4 & 3 & 18 & 3 & 1.4 & $0.4-4.6$ \\
\hline Intimate friend & 27 & 19 & 114 & 16 & 1.5 & $0.9-2.5$ \\
\hline Acquaintance & 18 & 12 & 68 & 10 & 1.7 & $0.9-3.1$ \\
\hline Drug dealer & 1 & 1 & 11 & 2 & 0.6 & $0.0-4.4$ \\
\hline Others\# & 14 & 10 & 98 & 14 & 0.9 & $0.5-1.7$ \\
\hline \multicolumn{7}{|l|}{ Drug injection\#\# } \\
\hline Without assistance & 23 & 16 & 201 & 28 & 1.0 & \\
\hline Sexual partner & 26 & 18 & 18 & 3 & 12.6 & $5.7-28.4$ \\
\hline Relative & 8 & 6 & 36 & 5 & 1.9 & $0.7-5.0$ \\
\hline Intimate friend & 56 & 39 & 304 & 43 & 1.6 & $0.9-2.8$ \\
\hline Acquaintance & 29 & 20 & 137 & 19 & 1.8 & $1.0-3.5$ \\
\hline Drug dealer & 2 & 1 & 7 & 1 & 2.5 & $0.3-14.4$ \\
\hline
\end{tabular}

* Data without information were excluded;

** Mantel-Haenszel Test/Fisher's Exact Test;

*** Acquired by the individual himself, relatives, or others (found, robbed, traded, unknown);

\# Health clinic, syringe-exchange project, agent, ground, robbed, unknown, drug dealer, unspecified:

\#\# Six observations were excluded. 
done it at some time in their lives, $44 \%$ of women and men in the last six months, $48 \%$ of women and $58 \%$ of men in the last month, and $34 \%$ of women and $36 \%$ of men in the last drug use session. Regarding receiving such equipment, $49 \%$ of women and $44 \%$ of men reported having received used syringes and/or needles at some time in their lives, $43 \%$ of women and $37 \%$ of men in the last six months, $68 \%$ of women and $61 \%$ of men in the last month, and almost $33 \%$ of men and women, in the last drug use session.

The results of the comparisons of sexual behavior of women and men (Table 3 ) demonstrate that an opposite sex partnership had a greater chance of being usual for women than for men $(\mathrm{OR}=2.0$; 95\%CI: $1.2-3.4)$; and greater chance of being casual for men $(58.0 \%$ versus $39.0 \%$ for women). Regular sexual partnership of the same sex were more frequently for women (OR $=8.2 ; 95 \% \mathrm{CI}: 2.7-25.0)$ and did not differ statistically between men and women when casual.

Report of consistent use of condoms in the last six months, defined here as "condom use in all sexual relations", was encountered in regular opposite-sex couples for one fourth of women and $27 \%$ of men. The suggestion to use condoms by one of the partners, compared to the suggestion by both partners (reference category), had a greater chance of being on the part of the woman (OR $=8.1$; 95\%CI: 3.8-17.2);

Table 3

Profile of sexual partners, condom use, and drugs use of female and male injection drug users (IDUs) during the six months before being interviewed. AjUDE-Brasil II Project, 2000/2001.

\begin{tabular}{|c|c|c|c|c|c|c|}
\hline \multirow[t]{2}{*}{ Characteristics $^{\star \star \star \star}$} & \multicolumn{2}{|c|}{ Females } & \multicolumn{2}{|c|}{ Males } & \multirow[t]{2}{*}{$O R^{\star \star \star}$} & \multirow[t]{2}{*}{$95 \% \mathrm{Cl}^{\#}$} \\
\hline & $\mathrm{n}$ & $\%$ & $\mathrm{n}$ & $\%$ & & \\
\hline \multicolumn{7}{|l|}{ Partners and condom use } \\
\hline Regular opposite sex & 106 & 83 & 408 & 72 & 1.97 & $1.2-3.4$ \\
\hline No condom use & 79 & 75 & 295 & 73 & 1.13 & $0.7-2.0$ \\
\hline Use suggested by the IDUs himself & 30 & 60 & 80 & 36 & 8.09 & $3.8-17.2$ \\
\hline Use suggested by IDUs' partner & 3 & 6 & 60 & 27 & 0.49 & $0.1-1.8$ \\
\hline Use suggested by both partners & 17 & 34 & 165 & 51 & 1.00 & $0.4-1.7$ \\
\hline Casual opposite sex & 48 & 39 & 331 & 58 & 0.46 & $0.3-0.7$ \\
\hline No condom use & 17 & 37 & 165 & 51 & 0.57 & $0.3-1.1$ \\
\hline Use suggested by the IDUs himself & 24 & 67 & 150 & 59 & 1.20 & $0.5-3.1$ \\
\hline Use suggested by IDUs' partner & 4 & 11 & 45 & 18 & 0.67 & $0.2-2.7$ \\
\hline Use suggested by both partners & 8 & 22 & 60 & 23 & 1.00 & $0.4-2.3$ \\
\hline Regular same sex & 9 & 36 & 12 & 6 & 8.16 & $2.7-25.0$ \\
\hline Casual same sex & 7 & 30 & 34 & 19 & 1.92 & $0.7-5.5$ \\
\hline \multicolumn{7}{|l|}{ Partners also use drugs } \\
\hline Regular opposite sex & 59 & 57 & 46 & 12 & 10.14 & $6.0-17.2$ \\
\hline Casual opposite sex & 22 & 50 & 57 & 18 & 4.49 & 2.2-9.1 \\
\hline Regular same sex & 5 & 56 & 5 & 45 & 1.50 & $0.2 ; 13.0$ \\
\hline Casual same sex & 4 & 57 & 11 & 35 & 2.42 & $0.4-17.4$ \\
\hline \multicolumn{7}{|l|}{ Sex under influence of drugs } \\
\hline Regular opposite sex & 61 & 59 & 201 & 52 & 1.30 & $0.9-2.1$ \\
\hline Casual opposite sex & 31 & 67 & 190 & 62 & 1.28 & $0.7-2.6$ \\
\hline \multicolumn{7}{|l|}{ Sex in exchange for drugs } \\
\hline Casual opposite sex & 20 & 43 & 39 & 12 & 5.52 & $2.7-11.4$ \\
\hline Casual same sex & 4 & 67 & 19 & 56 & 1.05 & $0.2-7.2$ \\
\hline
\end{tabular}

* Data without information were excluded (losses varied from 14 to 48 individuals). In all categories the comparison was done with no as reference, with the exception of these variables: "condom use" and "sex under the influence of drugs" in which comparison was done with always use and never use, respectively;

** Very small " $n$ " are not presented;

*** Comparisons restricted to yes and no;

\# Mantel-Haenszel Test/Fisher's Exact Test: 
condom use was suggested by the partner for $6 \%$ of women and $27 \%$ of men, indicating that women suggest using condoms more frequently than do men. Among casual partners, consistent use of condoms was mentioned by $63 \%$ of women and $49 \%$ of men; the suggestion to use condoms was made by $67 \%$ of women and $59 \%$ of men, and by the partner for $11 \%$ of women and $18 \%$ of men, when compared with the suggestion to use condoms being made by both partners.

A greater proportion of women than men reported using drugs with their partners of the opposite sex, having about ten times greater chance of doing them with regular partners $(\mathrm{OR}=10.1 ; 95 \% \mathrm{CI}: 6.0-17.2)$, and four and a half times greater with casual partners $(\mathrm{OR}=$ 4.5; 95\%CI: 2.2-9.1) considering no use of drugs as reference. As for drug use with same-sex partners, whether regular or casual, there was no significant difference. There was also no significant difference in the practice of sex with the opposite sex under the influence of drugs, either regular (59\% and $52 \%$ ), or casual partnership (67\% and $62 \%$, respectively, men and women).

Exchange of sex for drugs with casual partners of the opposite sex was reported five times more by women (OR $=5.5$; 95\%CI: 2.7-11.4). In casual couples of the same sex there was no significant difference.

\section{Comparison between HIV-seropositive women and men}

In this study, $39 \%$ of female and $36 \%$ of male IDUs were HIV seropositive. Table 4 presents the results of comparisons between them, in terms of sociodemographic and behavioral characteristics. Considering the median group age (31 years), a greater proportion of HIVseropositive women (53\%) show ages above the average as compared to men (46\%), though this difference is not significant. With regard to the education of those infected, women had less schooling (up to four years less) than men (OR = 2.0; 95\%CI: 1.0-3.8).

Half of IDUs with positive serology were from Porto Alegre, with $44 \%$ of women and $54 \%$ of men $(\mathrm{p}<0.05)$. In all the SEP, except São José do Rio Preto and Gravataí, the proportion of HIV-seropositive women was similar to that of men. Nevertheless, in São José do Rio Preto this proportion was significantly greater $(\mathrm{OR}=3.2$; 95\%CI: 1.4-7.4) and in Gravataí it was smaller $(\mathrm{OR}=0.5$; 95\%CI: 0.2-1.8), but not significant. Among IDUs recruited in Salvador, where a lower global rate of HIV infection was observed, women and men show similar rates $(5 \%$ and $4 \%$, respectively).

As regards marital status, infected women are more likely than infected men to be married $(\mathrm{OR}=2.6$; 95\%CI: $1.4-4.8$ ) or to be nonwhite (OR $=2.1$; 95\%CI: 1.1-3.9). Reported occupation does not differ between them.

Among HIV-infected IDUs, aspects of their introduction to injection drug use suggest that women mention with greater frequency that a sexual partner acted as facilitator in obtaining drugs (OR $=21.0$; 95\%CI: 4.6-105.4), in obtaining injection materials $(\mathrm{OR}=16.5$; 95\%CI: 2.8 $24.8)$, and in injecting the drugs for the first time $(\mathrm{OR}=31.4$; 95\%CI: 7.3-148.3), as compared to obtaining one's own, obtaining in a pharmacy, and injecting by oneself, respectively.

Although not significant, HIV-seropositive females had a greater chance than HIV-seropositive males of having sexual relations in the last six months with regular partners of the opposite sex (OR $=2.2$; 95\%CI: 0.9-5.4) and with casual partners of the same sex $(\mathrm{OR}=3.3 ; 95 \% \mathrm{CI}$ : 0.9-12.3).

Regarding drug use and sexual relations, infected women had a greater chance of having regular partners who also used drugs as compared to infected men $(\mathrm{OR}=10.4$; 95\%CI: 4.2 25.9), however no significant difference was observed between the proportion of men and women that reported having sex under the influence of drugs. Nevertheless, among casual partners, HIV-seropositive females had a greater chance of having sexual relations in order to obtain drugs $(\mathrm{OR}=4.3$; 95\%CI: $1.3-14.8$ ) than their male partners.

More than half of men and women that mention not using condoms consistently with regular partners of the opposite sex were infected with HIV. Among casual partners, a greater proportion of men (51\%) than women (18\%) who reported not using condoms consistently were infected $(\mathrm{p}=0.012)$.

Table 5 presents the results of the final multivariate model. It shows that education of less than four years (OR = 3.5; 95\%CI: 1.2-10.0), having been introduced by a sexual partner to injection drug use $(\mathrm{OR}=23.7 ; 95 \% \mathrm{CI}$ : 2.9-191.8), and having a regular partner that uses injection drugs (OR $=8.0$; 95\%CI: 2.9-22.6) were significantly associated with HIV-seropositive women when compared to men of the same serology status. All the OR obtained in the multivariate analysis after adjustment reflect different magnitudes than those obtained in the univariate analysis, indicating that the effect changed with the adjustment, although the nature and direction of the associations were maintained. 
Sociodemographic characteristics, initiation, injection drug use, and sexual practices among HIV-seropositive female and male injection drug users (IDUs). AjUDE-Brasil II Project, 2000/2001.

\begin{tabular}{|c|c|c|c|c|c|c|}
\hline \multirow[t]{3}{*}{ Characteristics* } & \multicolumn{4}{|c|}{$\mathrm{HIV+}$} & \multirow[t]{3}{*}{ OR } & \multirow[t]{3}{*}{$95 \% \mathrm{Cl}^{\star \star}$} \\
\hline & \multicolumn{2}{|c|}{ Females } & \multicolumn{2}{|c|}{ Males } & & \\
\hline & $\mathrm{n}$ & $\%$ & $\mathrm{n}$ & $\%$ & & \\
\hline Total & 57 & 39 & 254 & 36 & - & - \\
\hline Age (> 31 years) & 57 & 39 & 238 & 34 & 1.3 & 0.9-1.9 \\
\hline Education (up to 4 years) & 27 & 50 & 78 & 33 & 2.0 & $1.1-3.8$ \\
\hline \multicolumn{7}{|l|}{ Syringe-exchange program city } \\
\hline Porto Alegre & 25 & 44 & 137 & 54 & 1.0 & \\
\hline São José do Rio Preto & 16 & 28 & 27 & 11 & 3.2 & $1.4-7.4$ \\
\hline Itajaí & 5 & 9 & 25 & 10 & 1.1 & $0.3-3.4$ \\
\hline Florianópolis & 4 & 7 & 15 & 6 & 1.5 & $0.3-5.3$ \\
\hline Salvador & 3 & 5 & 10 & 4 & 1.6 & $0.3-7.2$ \\
\hline Gravataí & 4 & 7 & 40 & 16 & 0.5 & $0.2-1.8$ \\
\hline Marital status (Married) ${ }^{\star \star \star}$ & 28 & 49 & 69 & 27 & 2.6 & $1.4-4.8$ \\
\hline Skin color (non-white) & 32 & 56 & 97 & 38 & 2.1 & $1.1-3.9$ \\
\hline Without occupation in last 6 months & 19 & 37 & 81 & 33 & 1.2 & $0.6-2.3$ \\
\hline \multicolumn{7}{|l|}{ Obtaining drug at initiation } \\
\hline Individual himself or other means & 8 & 14 & 61 & 24 & 1.0 & \\
\hline Partner & 11 & 19 & 4 & 2 & 21.0 & $4.6-105.4$ \\
\hline Intimate friend & 17 & 30 & 66 & 26 & 2.0 & $0.7-5.4$ \\
\hline Acquaintance & 11 & 19 & 45 & 17 & 1.9 & $0.6-5.6$ \\
\hline Drug dealer & 10 & 18 & 78 & 31 & 1.0 & $0.3-2.9$ \\
\hline \multicolumn{7}{|l|}{ Obtaining equipment at initiation } \\
\hline Pharmacy & 30 & 53 & 165 & 65 & 1.0 & \\
\hline Partner & 6 & 10 & 2 & 1 & 16.5 & $2.8-24.8$ \\
\hline Relative & 1 & 2 & 7 & 3 & 0.8 & - \\
\hline Intimate friend & 8 & 14 & 31 & 12 & 1.4 & $0.5-3.6$ \\
\hline Acquaintance & 7 & 12 & 19 & 8 & 2.0 & $0.7-5.7$ \\
\hline Others & 5 & 9 & 30 & 11 & 1.0 & $0.3-3.1$ \\
\hline \multicolumn{7}{|l|}{ Injecting drug at initiation } \\
\hline Myself & 9 & 16 & 87 & 34 & 1.0 & \\
\hline Partner & 13 & 23 & 4 & 2 & 31.4 & 7.3-148.3 \\
\hline Relative & 6 & 10 & 17 & 7 & 3.4 & $1.0-12.4$ \\
\hline Intimate friend & 17 & 30 & 85 & 34 & 1.9 & $0.8-5.0$ \\
\hline Acquaintance & 12 & 21 & 57 & 23 & 2.0 & $0.7-5.7$ \\
\hline Regular partners opposite sex\# & 40 & 83 & 132 & 69 & 2.2 & $0.9-5.4$ \\
\hline Regular partners opposite sex use drugs\# & 24 & 60 & 16 & 13 & 10.4 & $4.2-25.9$ \\
\hline \multicolumn{7}{|l|}{ Sex under influence of drugs \#\# } \\
\hline Regular partner opposite sex & 23 & 59 & 65 & 52 & 1.3 & $0.6-2.9$ \\
\hline Casual partner opposite sex & 12 & 71 & 56 & 62 & 1.5 & $0.4-5.4$ \\
\hline \multicolumn{7}{|l|}{ Sex for drugs $\#$} \\
\hline Casual opposite sex & 8 & 47 & 16 & 17 & 4.3 & $1.3-14.8$ \\
\hline Casual same sex & 4 & 68 & 10 & 62 & 1.2 & $0.1-13.5$ \\
\hline
\end{tabular}

* Using no as reference;

** Mantel-Haenszel Test/Fisher's Exact Test;

*** Included married and co-residing;

\# Data without information were excluded;

\#\# For the variable "sex under the influence of drugs" never was used as reference. 
Comparison of unadjusted odds ratio with that adjusted by regression analysis for female compared to male HIV seroprevalent injection drug users (IDUs). AjUDE-Brasil II Project, 2000/2001.

\begin{tabular}{|c|c|c|c|c|c|c|}
\hline \multirow[t]{3}{*}{ Characteristics } & \multicolumn{4}{|c|}{ HIV+ } & \multirow{3}{*}{$\begin{array}{c}\text { Univariate } \\
\text { analysis* } \\
\text { OR } \text { Rnadjusted } \\
(95 \% \mathrm{Cl})\end{array}$} & \multirow{3}{*}{$\begin{array}{c}\text { Multivariate } \\
\text { analysis } \\
\text { OR }_{\text {adjusted }} \\
(95 \% \mathrm{Cl})\end{array}$} \\
\hline & \multicolumn{2}{|c|}{ Females } & \multicolumn{2}{|c|}{ Males } & & \\
\hline & $\mathrm{n}$ & $\%$ & $\mathrm{n}$ & $\%$ & & \\
\hline Total & 57 & 39 & 254 & 36 & - & - \\
\hline Education (up to 4 years) & 27 & 50 & 78 & 33 & $2.0(1.1-3.8)$ & $3.5(1.2-10.0)$ \\
\hline \multicolumn{7}{|l|}{ Injecting the drug at initiation } \\
\hline Myself & 9 & 16 & 87 & 34 & 1.0 & 1.0 \\
\hline Partner & 13 & 23 & 4 & 2 & $31.4(7.3-148 ; 3)$ & $23.7(2.9-191.8)$ \\
\hline Relative & 6 & 10 & 17 & 7 & $3.4(1.0-12.4)$ & $2.2(0.3-14.9)$ \\
\hline Intimate friend & 17 & 30 & 85 & 34 & $1.9(0.8-5.0)$ & $3.7(1.0-13.6)$ \\
\hline Acquaintance & 12 & 21 & 57 & 23 & $2.0(0.7-5.7)$ & $3.4(0.8-14.3)$ \\
\hline $\begin{array}{l}\text { Regular partners of the } \\
\text { opposite sex who use drugs }{ }^{\star \star}\end{array}$ & 24 & 60 & 16 & 13 & $10.4(4.2-25.9)$ & $8.0(2.9-22.6)$ \\
\hline
\end{tabular}

* Mantel-Haenszel Test;

** Binary logistical regression model adjusting for syringe-exchange program city and controlling for education, assistance with first injection and partner of the opposite sex who also uses drugs.

\section{Discussion}

This study of IDUs receiving assistance from SEP suggests that female users go through a different process than males, especially with regard to their sexual partners, who have a special role in introducing them to injection drugs for the first time, furnishing them with drugs and injection equipments (syringes and needles), and assisting in the very act of intravenous injection.

Among those infected with HIV, women reported more frequently than men partnerships with regular partners who also used drugs. Besides this, women were more likely to report sexual relations under the influence of drugs. On the other hand, a greater proportion of these women traded sex for drugs with casual partners when compared with infected men. All of these factors, as well as less education, nonwhite skin color, and being married, which are observed more frequently among women than men, indicate greater exposure to HIV infection.

These results are similar to the findings of international studies that women are more frequently initiated by men than are men by women, as in a study by Evans et al. 5, which compared female and male IDUs in San Francisco, United States. In contrast, however, a study by Doherty et al. 9 found $65 \%$ of women initiated by other women and $77 \%$ of men initiated by other men. However, the authors of this last study justified the divergence of their findings from those of previous studies based on the possibility of differential selection in their access to IDU initiates, a sample bias, or the eventuality of real change in this social group. In verifying the proportion of initiates in the present study, it was found that about $80 \%$ of IDUs, independent of sex, had more than three years of injection drug use, or rather, a reduced number of initiates were accessed relative to the study mentioned above. In counterpoint, and to some extend agreeing with our findings, Doherty et al. 9 verified that the women who were initiated by men had a profile of greater risk and greater HIV seroprevalence, suggesting little preventive control in needle sharing by women.

In general, our study demonstrated similarity between men and women with regard to age at initiation to general and injection drug use and syringe sharing. On the other hand, significant differences in how drugs and syringes were obtained, both recently at the interview as well as at the time of first injection, could suggest a more dependent and passive role for female IDUs 19.

Another distinguishing issue relative to female and male IDUs and the HIV/AIDS epidemic, characterizing them as groups with a double risk of infection by sharing used syringes and needles, is sexual contact without condoms. From a biological point of view, women are more susceptible to HIV infection, as much from the vaginal mucous tissue exposed to semen, which is more HIV concentrated than the vaginal fluid, as from the presence of STDs 20. 
From the point of view of behavior, sociocultural context can influence whether protection is used in sexual relations 21,22 . Some studies point out the difficulty in negotiating with a partner, confidence in fidelity, and romanticism of unconditional surrender, as factors that amplify risk conditions for women, increasing their vulnerability 19,20,23,24.

Given all of the characteristics mentioned above, the greater degree of sexual risk encountered among women than men can be attributed to the fact that, in this study, women reported with more frequency than men partners who are also IDUs, sex under the influence of drugs, and trade of sex for drugs, corroborating the hypothesis that female Brazilian IDUs are more exposed than men to HIV infection.

Therefore, the increase in these two behavioral risks, sex and drugs, among the women of this study suggests that they have less control and autonomy than men as concerns HIV infection. These findings agree with those of Friedman et al. 25 and Doherty et al. 9,26, which reaffirm the double risk of infection, principally for women that inject with their partners.

Various studies agree that women are highly influenced by their sexual partners, principally when they interact with members of their injection network 27,28,29,30. The IDUs accessed in the present study shared with friends, acquaintances, partners, or, in other words, their use network. As much for women as for men, the higher proportion of injection equipment sharing in one's lifetime presupposes the possibility that sharing continues to happen after one's introduction to injection drug use. Evans et al. 5 found that in addition to starting to use injection drugs with their sexual partners, women also shared equipment with them.

Again, the results discussed above do not agree with those obtained by Doherty et al. 9 , who found $44 \%$ of women and $33 \%$ of men buying their own needles for the first use episode. Also, Crofts et al. 31 , studying the circumstances of injection, found that $50 \%$ of initiates acquired their own needles. In our study, $43 \%$ of women and $55 \%$ of men acquired their equipment from a pharmacy.

The presence of women with less education and with greater proportion of non-white skin color suggests a less favorable position for this group that increases their vulnerability to HIV infection. An analysis of the interrelationships of HIV vulnerability and social inequalities, prejudice, and marginalization, presented by Bastos \& Szwarcwald 32 , shows the importance of inequality and of racial and gender prejudice. Worldwide, the exposure of women increases with social vulnerability 1,33. In Brazil, the epidemic advances disproportionately among the black and mulatto population 2 and the category of women most affected is that of lower income and less education 34 .

The finding that women suggest using condoms to their partners more frequently than do men may be considered an advancement. However, we should recognize that, based on specific studies, in the majority of cases women's power in negotiating with their sexual partners is presumed to be limited $35,36,37$.

Before presenting our conclusions, below, some limitations of this study should be recognized. In the first place, the data used here were not originally collected for our research question, only allowing for partial understanding. We acknowledge the absence of more complete information about aspects related to initiation, including age, motives for experimentation and continuation of drug use, as well as perception of one's own situation, personal antecedents for initial use. All of which would contribute to delineating a more comprehensive profile of female and male IDUs.

The possibility of comparing the findings we present here with national and international studies is limited because there are few studies that address initiation among IDUs in a similar fashion. Some address young IDUs in order to more precisely characterize initiation, while others access more mature IDUs cohorts. Also, the dissimilarity of results may be attributed as much to distinct recruitment strategies as to when and where research was undertaken. The generalization of these findings is reduced considering that the sample could not representative of the Brazilian IDUs population. Furthermore, there is a limitation in the time between exposure and event imposed by the cross-sectional delineation of the study.

Although the sample included a lower proportion of women than men, which at time generated ample confidence intervals, in our understanding, the greatest merit of the present study is having accessed an expressive number of female IDUs, a population that remains undescribed in Brazilian studies.

The results presented here have important implications for public health. Standing out is the fact that women are subject to greater risk of infection by HIV than are men due to greater prevalence of factors associated with HIV deriving from their initiation to the use of injection drugs, as has been affirmed by other authors 8,26 . In addition, the prevalence among women of receiving assistance in the act of injection may function as a predictor of HIV se- 
roconversion. Since it is men that appear to be most involved in initiating women, independent of other circumstances, it seems that the sexual IDUs partnership of any marital status should be included in studies on this topic, and thus demand new investigative methods that include qualitative and quantitative methodological approaches, among others 38,39,40.

Furthermore, preventive measures should consider the specificities of gender, looking principally to reach women who are initiated by men. Interventions focusing on the sexual partnership appear to be an urgent necessity for understanding fundamental questions of harm reduction relative to prevention, since the use of drugs is common within couples.

Another important question has to do with the specificities of each location. The Health Ministry estimates that SEP were capable of reducing the AIDS cases among IDUs by $49 \%$ in a span of almost 10 years (between 1993 and 2002) 2. However, the south of Brazil, principally, Porto Alegre, still shows increasing AIDS notifications among IDUs (around $25 \%$ of cases) 2 . Various interacting factors contribute to differences in seropositivity among the diverse re-

\section{Resumo}

Este estudo teve como objetivo comparar homens e mulheres usuários de drogas injetáveis (UDIs) quanto ao perfil sócio-demográfico e aspectos da iniciação ao uso de droga injetável. Constou de estudo transversal, multicêntrico, realizado entre 2000/2001, em seis Programas de Redução de Danos brasileiros. Foram entrevistados 146 mulheres e 709 homens, com médias de idades de 29,5 e 28,3 anos, respectivamente. Ambos os grupos iniciaram o uso de drogas injetáveis com idades semelhantes, 18,6 e 19,3 anos, respectivamente para mulheres e homens, porém elas foram mais freqüentemente iniciadas por parceiros sexuais na obtenção da droga, seringas e no ato de injeção. Comparadas aos homens, mulheres relataram significativamente mais parcerias sexuais regulares (83\% versus $72 \%$ ); menos eventuais (39\% versus 58\%), maior uso de drogas injetáveis com seus parceiros, além da "troca" de sexo por drogas. Entre HIV-soropositivos, mulheres apresentaram menor escolaridade, tiveram mais chance de contar com a participação de parceiro sexual em sua iniciação com drogas injetáveis, além de relatarem mais freqüentemente parceiros sexuais que usavam esse tipo de droga. As mulheres UDIs apresentaram aspectos comportamentais sugestivos de maior vulnerabilidade à infecção pelo HIV do que os homens.

Uso Indevido de Drogas Parenterais; HIV; Síndrome de Imunodeficiência Adquirida; Redução do Dano gions of the country, such as migration for noninjection drugs and the influence of cocaine trafficking in border regions, mainly in the south. Continued research among SEP is fundamental for maintaining the results already obtained and reverting to the high prevalences of certain regions $41,42,43$.

All aspects of our analysis point to the importance of identifying a concept in public health that addresses individual and collective aspects related to the degree and mode of exposure to infection and illness by HIV and, inseparably, to greater or lesser access to the resources that are necessary for protecting oneself. The concept of vulnerability 36 appears an appropriate solution, since it helps in discussions of inequality relative to HIV/AIDS by proposing a redefinition of notions of individual or group risk in terms of social vulnerability 44 .

Therefore, we suggest that should be addopted for studying the IDUs population 45 methodological procedures that extend epidemiology beyond risk, recognizing analysis of vulnerability as a fundamental tool for comprehending and managing the HIV/AIDS epidemic.

\section{Contributors}

All authors participated in developing the study's concept, design, and data analysis, as well as in writing the article.

\section{Other members of the AjUDE-Brasil II Project}

T. Andrade, F. I. Bastos, R. T. Caiaffa, I. M. Cardoso, A B. Carneiro-Proietti, M. A. B. Chagas, S. Deslandes, D. Doneda, R. E. M. Eller, E. M. A. Ferreira, D. Gandolfi, M. Hacker, N. Januário, R. Knoll, A. C. S. Lopes, A. C. Maia, M. Malta, R. C. R. Marinho, D. L. Matos, R. M. B. Mayer, H. F. Mendes, E. A. Mendonça, I. F. M. Picinim, F. A. Proietti, R. C. Silva, M. D. S. Sudbrack. 


\section{Acknowledgements}

The AjUDE-Brasil II Project was done by the Federal University of Minas Gerais (Universidade Federal de Minas Gerais), with the technical and financial assistance of the Cooperation Project (Projeto de Cooperação) between the National STD/AIDS Project (Projeto Nacional de DTS/AIDS) and the Organizations United Against Crime and Drugs Office (Escritório das Organizações Unidas contra o Crime e Drogas), no. AD/BRA/99/E02.

Drs. W. T. Caiaffa, F. I. Bastos, and F. A. Proietti are recipients of Brazilian Council for Scientific and Technological Development (CNPq) scholarships.

\section{References}

1. The Joint United Nations Programme on HIV/ AIDS. AIDS epidemic update. Global summary the AIDS epidemic, December 2004. http://www. unaids.org/en/default.asp (accessed on 20/Mar/ 2005).

2. Ministério da Saúde. Boletim EpidemiológicoAIDS, Ano I n. 01, 01-26a semanas epidemiológicas, janeiro a junho de 2004. http://www.aids. gov.br/final/biblioteca/BOLETIM2.pdf (accessed on 05/May/2005).

3. Ministério da Saúde. Tabela VIII - casos de Aids em indivíduos do sexo feminino com 13 anos de idade ou mais, segundo categoria de exposição hierarquizada e ano de diagnóstico. Brasil, 1983 a 2003. Boletim Epidemiológico-AIDS. Ano XVII, n. 01, 01-52 semanas epidemiológicas, janeiro a dezembro de 2003. Brasília: Ministério da Saúde; 2004. p. 33.

4. Strathdee AS, Galai N, Safaiean M, Celentano DD, Vlahov D, Johnson L, Nelson KE. Sex differences in risk factors for HIV seroconversion among injection drug users. Arch Intern Med 2001; 161: 1281-8.

5. Evans JL, Hahn JA, Page-Shafer K, Lum PJ, Stein ES, Davidson PJ, et al. Gender differences in sexual and injection risk behavior among active young injection drug users in San Francisco (the UFO Study). J Urban Health 2003; 80:137-46.

6. De Boni R, Pechansky R, Van Diernen L, Kessler F, Surratt H, Inciardi J. Diferenças entre fatores de risco para infecção pelo HIV em UDI do Rio de Janeiro e Porto Alegre. Rev Psiquiatr Clín 2005; 32:5-9.

7. Ribeiro Filho AD. A pertinência da consulta ginecológica nos centros de testagem anônima (CTA) do vírus da imunodeficiência humana (HIV) [Tese de Doutorado]. Campinas: Faculdade de Ciências Médicas, Universidade Estadual de Campinas; 1997.

8. Spittal PM, Craib KJP, Wood E, Laliberté N, Li K, Tyndall MW, et al. Risk factors for elevated HIV incidence rates among female injection drug users in Vancouver. CMAJ 2002; 166:894-9.
9. Doherty MC, Garfein RS, Monterroso E, Latkin C, Vlahov D. Gender differences in the initiation of injection drug use among young adults. J Urban Health 2000; 77 Suppl 3:396-414.

10. Dwyer R, Richardson D, Ross MW, Wodak A, Miller ME, Gold J. A comparison of HIV Risk between women and men who inject drugs. AIDS Educ Prev 1994; 6 Suppl 5:379-89.

11. Grimberg M. Gênero y VIH/Sida: un análisis de los diferenciales de género en la experiencia de vivir com VIH. Cuad Med Soc 2000; 78:41-54.

12. Bastos FI. Ruína e reconstrução. AIDS e drogas injetáveis na cena contemporânea. Rio de Janeiro: Editora Relume-Dumará/Associação Brasileira Interdisciplinar de AIDS/Instituto de Medicina Social, Universidade do Estado do Rio de Janeiro; 1996.

13. Astemborski J, Vlahov D, Warren D, Solomon L, Nelson KE. The Trading of sex for drugs or money and HIV seropositivity among female intravenous drug users. Am J Public Health 1994; 84 Suppl 3:382-7.

14. Caiaffa WT. Projeto AjUDE-Brasil. Avaliação epidemiológica dos usuários de drogas injetáveis (UDI) dos Projetos de Redução de Danos (PRD) apoiados pela CN-DST/AIDS. http://www.aids. gov.br (accessed on 20/Jan/2004).

15. Proietti ABFC, Gonçalves VF, Eller REM. Padronização dos testes sorológicos. In: Caiaffa WT, organizadores. Projeto AjUDE-Brasil. Avaliação epidemiológica dos usuários de drogas injetáveis (UDI) dos Projetoss de Redução de Danos (PRD) apoiados pela CNDST/Aids. Série Avaliação. Brasília: Ministério da Saúde; 2001.

16. Schlesselman JJ. Case-control studies. Design, conduct, analysis. New York: Oxford University Press; 1982.

17. Agresti A. Categorical data analysis. New York: John Wiley; 1990.

18. Hosmer DW, Lemeshow S. Applied logistic regression. New York: John Wiley \& Sons; 2000.

19. Hser YI, Angelin MD, Mcglothlin W. Sex differences in addict careers. 1. Initiation of use. Am J Drug Alcohol Abuse 1987; 13:33-57. 
20. Chiriboga CR. Introducción. Mujer y SIDA: conceptos sobre el tema. In: Rico B, Vandale S, Allen $\mathrm{B}$, Liguori AL, editors. Situación de las mujeres y el VIH/SIDA en América Latina. Cuernavaca: Instituto Nacional de Salud Pública; 1997. p. 22.

21. Santos NJS. As mulheres e a Aids [Dissertação de Mestrado]. São Paulo: Faculdade de Saúde Pública, Universidade Federal de São Paulo; 1994.

22. Parker R. Corpos, prazeres e paixão: a cultura sexual no Brasil contemporâneo. São Paulo: Editora Best Seller; 1991.

23. Barbosa RM. Negociação sexual ou sexo negociado? Poder, gênero e sexualidade em tempos de AIDS. In: Barbosa RM, Parker R, organizadores. Sexualidade pelo avesso: direitos, identidades e poder. São Paulo: Editora 34/Rio de Janeiro: Instituto de Medicina Social, Universidade do Estado do Rio de Janeiro; 1999. p. 73-88.

24. Parker R, Galvão J. Quebrando o silêncio: mulheres e Aids no Brasil. Rio de Janeiro: Associação Brasileira Interdisciplinar de AIDS/Instituto de Medicina Social, Universidade do Estado do Rio de Janeiro/Editora Relume-Dumará; 1995.

25. Friedman SR, Furst RT, José B, Curstir R, Neaigus A, Des Jarlais DC, et al. Drug scene roles and HIV risk. Addiction 1998; 93:1403-16.

26. Doherty MC, Garfein RS, Monterroso E, Brown D, Vlahov D. Correlates of HIV infection among young adult short-term injection drug users. AIDS 2000; 14:717-26.

27. Barcellos C, Bastos FI. Redes Sociais e a difusão da Aids no Brasil. Bol Oficina Sanit Panam 1996; 121:11-24.

28. Friedman SR, Neaigus A, Jose B, Goldstein M, Curtis R, Des Jarlais DC. Gender differences in HIV seroprevalence among new injectors vary city and by social network. In: HIV Injection in Women Conference, Abstract 82. Washington DC; 1995; p. 22-5.

29. Davies AG, Dominy NJ, Peters AD, Richardson AM. Gender differences in HIV risk behaviour of injecting drug users in Edinburgh. AIDS Care 1996; 8:517-27.

30. Telles PR, Bastos FI. O contexto do uso de drogas em cinco cidades brasileiras. Boletim ABIA 1995; (27):10-2.

31. Crofts N, Louie R, Rosenthal D, Jolley D. The first hit: circumstances surrounding initiation into injection. Addiction 1996; 91 Suppl 8:1187-96.

32. Bastos FI, Szwarcwald CL. AIDS e pauperização: principais conceitos e evidências empíricas. Cad Saúde Pública 2000; 16 Suppl 1:65-76.

33. United Nations Population Fund. State of world population 2005. http://www.unfpa.org/swp/index.htm (accessed on 05/Oct/2005).

34. Ministério da Saúde. Diretrizes e políticas de prevenção e controle das DST/AIDS entre mulheres. Programa Nacional de DST/AIDS, 1997. http:// www.aids.gov.br/prevencao/mulhe_diret.htm (accessed on 10/Jan/2003).
35. Oliveira MCC. Singularidades do luto por Aids em mulheres. As viúvas da Aids [Dissertação de Mestrado]. São Paulo: Programa de Psicologia Clínica, Pontifícia Universidade Católica; 2000.

36. Ayres JRCM, França Jr. I, Calazans GJ, Saletti Filho HC. Vulnerabilidade e prevenção em tempos de AIDS. In: Barbosa RM, Parker R, organizadores. Sexualidade pelo avesso: direitos, identidades e poder. São Paulo: Editora 34/Rio de Janeiro: Instituto de Medicina Social, Universidade do Estado do Rio de Janeiro; 1999. p. 49-72.

37. Ferreira MP. Conhecimento e percepção de risco sobre o HIV/AIDS: um perfil da população brasileira no ano de 1998. Cad Saúde Pública 2003; 19 Suppl 2:S213-22.

38. Bastos FI, Coutinho K. A epidemia pelo HIV/Aids entre usuários de drogas injetáveis (UDI) no Brasil: cenários. In: Ministério da Saúde, organizador. A epidemia de AIDS no Brasil: situação e tendências. Brasília: Ministério da Saúde; 1997. p. 7186.

39. Friedman SR, Friedmann P, Telles PR, Bastos FI New injectors and HIV risk. In: Stimson G, Des Jarlais DC, Ball A, editors. Drug injecting and HIV infection: global dimensions and local responses. London: UCL Press; 1997. p. 76-90.

40. Goodfrey C, Wiessing L, Hartnoll R, editors. Modelling drug use: methods to quantify and understand hidden processes. Lisbon: European Monitoring Centre for Drugs and Drugs Addiction; 2001.

41. Caiaffa WT, Bastos FI. Usuários de drogas injetáveis e infecção pelo vírus da imunodeficiência humana: epidemiologia e perspectivas de intervenção. Rev Bras Epidemiol 1998; 1:190-202.

42. Caiaffa WT, Bastos FI, Proietti FA, Reis ACM, Mingotti SA, Gandolfi D. Practices surrounding syringe acquisition and disposal: effects of Syringe Exchange Programs (SEP) from different Brazilian regions - The AjUDE-Brasil II Project. Int J Drug Policy 2003; 14:365-71.

43. Caiaffa WT, Mingoti AS, Proetti FA, Proetti ABC, Reis ACM, Doneda D, Gandolfi D. The Dynamics of the Human Immunodeficiency Virus (HIV) epidemics in South of BraziI: increasing role of injecting drug users (IDU). Clin Infec Dis 2003; 15:71-81.

44. Parker R, Camargo Jr. KR. Pobreza e HIV/AIDS: aspectos antropológicos e sociológicos. Cad Saúde Pública 2000; 16 Suppl 1:89-102.

45. Purcell DWJD, Metsch LR, Latka M, Santbanez S, Gomez CA, Eldred L, et al. Interventions for seropositive injectors-research and evaluation: an integrated behavioral intervention with HIVpositive infection drug users to address medical care, adherence and risk reduction. J Acquir Immune Defic Syndr 2004; 37:S110-8.

Submitted on $04 / \mathrm{Jul} / 2005$

Final version resubmitted on 09/Nov/2005 Approved on 10/Nov/2005 